\title{
Nutcracker syndrome or pelvic venous congestion syndrome with Nutcracker anatomy: a case report
}

\author{
Majda Vrkić Kirhmajer*, \\ Dražen Perkov, \\ Ljiljana Banfić, \\ Albert Despot, \\ Luka Novosel, \\ Mario Lušić
}

University of Zagreb School of Medicine, University Hospital Centre Zagreb, Zagreb, Croatia
RECEIVED:

July 25, 2015

ACCEPTED:

September 17, 2015
KEYWORDS: Nutcracker syndrome, pelvic, congestion.

CITATION: Cardiol Croat. 2015;10(9-10):243. | DOI: http://dx.doi.org/10.15836/ccar.2015.243

*ADDRESS FOR CORRESPONDENCE: Majda Vrkić Kirhmajer, Klinički bolnički centar Zagreb, Kišpatićeva 12, HR-10000 Zagreb, Croatia. / Phone: +385-1-2367-505 / E-mail: majda_vrkic@yahoo.com

ORCID: Majda Vrkić Kirhmajer, http://orcid.org/0000-0002-1340-1917 • Dražen Perkov, http://orcid.org/0000-0001-5398-059X Ljiljana Banfić, http://orcid.org/0000-0002-4538-8980 • Luka Novosel, http://orcid.org/0000-0001-7515-9110

Mario Lušić, http://orcid.org/0000-0002-7654-2274

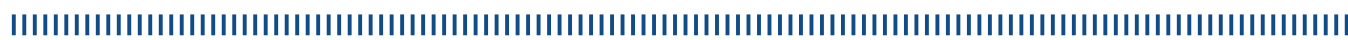

INTRODUCTION: Entrapment of the left renal vein (LRV) between the aorta and superior mesenteric artery (SMA) is known as Nutcracker phenomenon. Due to impeded outflow from LRV into the inferior vena cava and consequently LRV hypertension, a variety of symptoms can occur forming a Nutcracker syndrome (NCS). ${ }^{1,2}$ Clinical manifestations include hematuria, proteinuria, flank pain, dyspareunia, pelvic congestion and fatigue. Diagnostic criteria for NCS are not firmly established and treatment is controversial. We present a case of a 38-year old female with Nutcracker anatomy, pelvic varicosities and no clear signs of LRV hypertension.

CASE REPORT: The patient was referred in our institution because of large pelvic varicosities noticed on transvaginal Colour Doppler Ultrasound (CDUS). She complained on pelvic pain, fatigue and dyspareunia. Besides asthenic constitution her physical examination was unremarkable. Laboratory results were nonspecific, with no hematuria or proteinuria. CT scan showed compression of LRV between the aorta and SMA, enlarged left ovarian vein (LOV) and huge pelvic varicose veins. We did not find signs of elevated renocaval pressure gradient by CDUS. Taking into consideration the possible risks involved with LRV stenting, embolisation of the insufficient LOV by foam and coils was done only. This low risk procedure went well and her pelvic symptoms gradually resolved. On control CDUS and MR scan (after 3 months) the dilated pelvic veins were significantly reduced in size, with unchanged anatomy and flow velocities of LRV. Creatinine clearance and urine analyses were repeatedly normal.

CONCLUSION: In a patient with Nutcracker anatomy and predominantly pelvic congestion symptoms without significant renocaval pressure gradient, ovarian vein embolisation without LRV stenting can provide complete resolution of symptoms. Since gonadal veins may serve as an outflow conduit, in some cases their interruptions may worsen NCS symptoms, so follow up is needed.

LITERATURE IIIIIIIIIIIIIIIIIIIIIIIIIIIIIIIIIIIIIIIIIIIIIIIIIIIIIIIIIIIIIIIIIIIIIIIIIIIIIIIIIIIIIIIIIIIIIIIIIIIIIIIII

1. Gulleroglu K, Gulleroglu B, Baskin E. Nutcracker syndrome. World J Nephrol. 2014;3(4):277-81. Dol: http://dx.doi.org/10.5527/wjn.v3.i4.277

2. Kurklinsky AK, Rooke TW. Nutcracker phenomenon and nutcracker syndrome. Mayo Clin Proc. 2010;85(6):552-9.

DOI: http://dx.doi.org/10.4065/mcp.2009.0586 